\title{
Sensorial descriptors for CATIE and Folk pigeon pea (Cajanus cajan) salad determined through a focus group
}

\author{
Carolina Amerling Quesada \& Carmen Andrés Jiménez \\ Universidad Estatal a Distancia, San José Costa Rica; camerling@uned.ac.cr, candres@uned.ac.cr
}

Received 18-VI-2013 • Corrected 22-8-2013 • Accepted 1-II-2014

\begin{abstract}
Pigeon pea (Cajanus cajan) is known for its ability to fix Nitrogen into the soil, to protect water basins and for its high nutritional value. In Costa Rica the legume is cultivated in San Carlos by a small association of pigeon pea, root and tuber farmers. With the objective of supporting marketing efforts, we used a focus group to test a salad made from pigeon pea and other ingredients. The salad was evaluated by ten consumers regarding market tendencies, competitors, ingredients, taste, packaging material, appearance and commercial opportunities. The product was highly accepted and described by the consumers as versatile and the trends in which it can be found in the market were pleasure, health and convenience. They preferred biodegradable packaging material with nutritional facts label. Its long shelf life compared to other salads is an asset, even if it is more expensive than competing salads. The acceptance of the product suggests its possibility of success and the importance of studying other aspects.
\end{abstract}

KEY WORDS: Pigeon pea, focus group, salads, market, sensorial descriptors.

\section{RESUMEN}

El gandul (Cajanus cajan) es conocido por su capacidad de fijar nitrógeno en el suelo, así como proteger las cuencas hidrográficas y su alto valor nutricional. En Costa Rica se cultiva en San Carlos, Costa Rica por la Asociación de Productores de Gandul, Raíces y Tubérculos. Con el objetivo de apoyar los esfuerzos de mercadeo, se utilizó un grupo focal para probar una ensalada de gandul y otros ingredientes. La ensalada fue evaluada por diez consumidores según las tendencias del mercado, competidores, ingredientes, degustación, material de empaque, apariencia y venta del producto. El producto fue altamente aceptado y descrito por los consumidores como versátil y la tendencia en cuanto a la adquisición del producto eran placer, salud y conveniencia. Prefirieron el empaque biodegradable y con información nutricional. Su vida útil más larga en comparación con otras ensaladas es una ventaja, aunque sea más costosa. La aceptación del producto sugiere su posibilidad de éxito y la importancia de continuar investigando otros aspectos.

PALABRAS CLAVE: Gandul, grupo focal, formulación de producto, posicionamiento en el mercado, descriptores sensoriales.
Pigeon pea (Cajanus cajan (L.) Millsp.) is a legume known for its high nutritional value, especially on protein and vitamins $A$ and $C$ (MAG, 1991) and the fact that its amount of protein can range from 18 to 24\% (Nwosu; Ojukwu; Ogueke; Ahaotu \& Owuamanam, 2013) makes it an option for Food Security. It can also contribute to the environment, since it increases the capacity of trees to fix Nitrogen into the soil and can protect water basins.

Pigeon pea products have been developed in different countries around the world such as Panama (a traditional Christmas dish) (Paul \& Weber, 2013); India (fresh, frozen and canned) (Pandey; Pandey; Kumar \& Tiwari, 2013) and in Uganda (canned) (Ronner \& Giller, 2013) among many others. Dominican Republic, Colombia, Peru, Puerto Rico and the USA import these products as well.
The pea was planted in San Carlos, Costa Rica four years ago, due to an initiative from the Distance State University (UNED) and the Costa Rican Electricity Institute (ICE), generating very good results in production and resistance to weather and plagues.

New products from pigeon pea have been developed by the Agro-industry Chamber since 2012 (Andrés, 2013a; Andrés, 2013b \& Andrés, 2013c). For this study, a legume salad made with pigeon pea was used and it was designed and tested for the first time by Costa Rican consumers in a Pigeon Pea Fair celebrated in 2012 and its acceptance was very high. This is why a focus group about this product was organized to determine its sensorial descriptors which would lead to conclusions and further research. 
A focus group is a qualitative form of investigation that defines wishes and needs from the consumers in order to satisfy them and make it attractive for a specific market (Ivankovich, 2012). The technique is widely applied around the world to assess the quality and acceptance of industrialized food (Hartman; Wadsworth; Penny; Assema \& Page, 2013; Kher; De Jonge; Wentholt; Deliza; de Andrade; Cnossen \& Frewer, 2013; Sijtsema; Zimmermann; Cvetković; Mora \& Zaouche-Laniau, 2013).

The purpose of this study is to gather as much information as possible about a pigeon pea salad through a focus group, which was used to determine market tendencies, advantages and disadvantages against competitors, ingredients, packaging material, appearance and commercial opportunities.

\section{MATERIALS AND METHODS}

Formulation of the product: The legume salad used in this study was tasted at the Distance Education University in a Research and food fair. Its acceptance was very high and therefore a focus group was decided to be done to get more information.

The main raw material was pigeon pea. The varieties CATIE, Folk, Enana, Panama and Sabalito were analyzed. The rest of the ingredients used were corn, chick pea, petit poise, green celery, purple onion, red pepper, olive oil, white vinegar, salt, paprika and black pepper.

The formula of the product was designed so that pigeon pea was the main ingredient and the consumer could detect its flavor and see it as a new product. The criterion used to define the quantity of pigeon pea to include in the salad was that it would be one third of the ingredients.

The industrial equipment recommended for this process is: blancher, weighing scales, cutter, mixer, filler, packaging machine, labeler, palletizer (see appendix 1 for flowchart).

Focus group : The focus group was performed by 10 non trained people, which is the amount of people recommended by Anzaldúa-Morales (1994). They were gathered in a small office at the Exact and Natural Sciences school of UNED. The goal of the focus group was to generate the most important descriptors for a legume salad which main ingredient was pigeon pea.

The participants were chosen based on their interest in the product and their willingness to participate and give new ideas.
The following steps were followed to conduct the focus group:

Product and the focus group: The moderator thanked the members of the focus group for their participation. Afterwards, the characteristics of the product were explained to them as well as the commercial goals of the project.

Participants were asked what they knew about pigeon pea, such as its origin, their opinion and possibilities to use it as an ingredient. Then they were asked to determine the market trend to which the product belonged. They could choose one or more of the following trends: environmentally friendly, natural, healthy, convenience, exotic, price, different.

The way the salad can compete against similar products was discussed, analyzing advantages and disadvantages. A discussion about which ingredients needed to be added or taken out of the product took place among all participants. Participants tasted the product and expressed their opinion regarding texture, color, appearance and flavor. Building upon these organoleptical characteristics, consumers generated sensorial descriptors in a general way. The goal of this tasting was not to get quantitative data, but qualitative descriptors of the product.

An analysis of the ideal packaging material was done as well as the characteristics it should have, the type of material and its size. The possibility of selling the product in supermarkets, restaurants and hotels was discussed as well as the strategies to get it done.

\section{RESULTS}

The consumers knew pigeon pea from the other studies done at UNED (Andrés, 2013a; Andrés, 2013b \& Andrés, 2013c). Some also knew the product from Panama or Dominican Republic. Consumers believe that pigeon pea is good not only for their health but also for the environment. Actually, some of them mentioned its effects as a pesticide. Moreover, they highlighted a high acceptance and versatility.

The most important product mentioned was the hummus kind dip designed by Andrés (2013c). The most important trend defined by the consumers for this product was pleasure, the second one was healthy and the last one was convenience (the last one being related to "ready to eat"). 
Since the salad does not have lettuce, consumers agreed it would be a different and attractive option for the market, for safety and shelf life reasons. As for the shelf life, participants mentioned that this salad has a relatively low $\mathrm{pH}$, with no dressing or tuna, like other salads, which increases its shelf life.

Lastly, due to its ingredients, this salad cannot be sold as a normal lettuce and tomato salad, but as a gourmet product. Even if it were more expensive, consumers expressed they would be willing to pay for it.

The ingredients the consumers suggested could be added to the salad were: garlic, mushrooms, hot pepper, tuna, pasta, olives, dill, and parsley. Moreover, consumers suggested that the amount of pigeon pea could be increased in order to enhance the taste.

The tasting of the product had a high acceptance among the participants and positive comments. There were no negative comments on its taste. The sensorial descriptors generated by the consumers were: "good presentation", "good taste", "attractive colors" and "innovative".

Consumers suggested different recipes to be printed on the label of the product, so that people can get to know the product and its versatility. Moreover, the use of environmentally friendly packaging material was considered fundamental by the consumers as well as the possibility of seeing the product through the packaging material. Lastly, nutritional facts were requested.

The product is versatile and could be sold in different areas of the food market, among which were mentioned vegetarian restaurants, supermarkets and hotels. A suggestion on how to serve it was as an appetizer or a side dish.

\section{DISCUSSION}

This study revealed valuable and positive information about the pigeon pea salad. Other studies have been done about other products made from pigeon pea, like hummus kind dip (Andrés, 2013c), in which two mini focus groups were performed, generating the most important descriptors for each product and its acceptance after tasting it.

An acceptance study done by Andrés, Amerling \& Saravia, (2013) on the salad, also revealed its approval, going from a moderate level ( $37.8 \%$ of consumers) to a high level (62.2\%).
In this study, the fact that the salad is a new product was a positive asset, but it does not coincide with other studies. A recent study about honey, in which familiarity appeared to be positive considered with respect to the local honeys versus novel honeys could be 'too' novel for the consumers resulting in negative emotional responses (Stolzenbach; Bredie \& Byrne, 2013). This is a risk that needs to be considered when launching the product; nevertheless, if it has been accepted by consumers, the probability of success is higher.

According to other studies, the fact that the pigeon pea salad is so versatile is advantageous. For example, soy has been used for many different products. Adelakun; Duodu; Buys \& Olanipekun, 2013, used it for fortification due to its nutritional value, which could be considered in further investigations about pigeon pea.

The trends found in this article related to the environment and people's health coincide with another study which described wild and farmed fish through a focus group and found consumers expressed their environmental concerns as well as health issues (Katrin \& Ystgaard, 2013).

Also, related to the health concern, two studies support it. The first one by Slining; Wen \& Popkin, 2013, found how calorie-reduction food companies are removing voluntarily calories from their products as a consequence of consumers' suggestions. The second study by McCarthy; Cluzel; Dressel \& Newton, 2013, concluded in a study about food and health in Europe, that more research on healthy eating needs should be conducted in order to prevent obesity.

As for the fact that it is important for the participants that this product has nutritional facts on its package, a similar study about the packaging material of orange juice found out that the nutritional information on vita$\min C$, no preservatives and low price grouped the ideal packaging of orange juice for most participants (Gadioli; de Lacerda de Oliviera; Da Silva; Bezerra; Queiroz \& Chiarello, 2013).

Since this salad was described as a gourmet product, we recommended acceptance tests and focus groups in luxury hotels, restaurants and supermarkets, just like a similar study recommends (Veríssimo \& Correia, 2013).

As a conclusion, the product's acceptability test shows that pigeon pea is in a good marketing path. Its properties, industrial process and shelf life are recommended to be studied with physical chemical, shelf life, microbiological and sensorial studies. 


\section{REFERENCES}

Adelakun, O. E., Duodu, K. G., Buys, E., \& Olanipekun, B. F. (2013). Potential Use of Soybean Flour (Glycine max) in Food Fortification. INTECH. Open science, open mind. Retrieved from http://cdn.intechopen.com/pdfs/40001/ InTech-Potential_use_of_soybean_flour_glycine_max_ in_food_fortification.pdf

Andrés, C. (2013a). Sensory evaluation for consumer acceptance testing of Sabalito gandul bean (Cajanus Cajan (L.) Millsp.) stew in Costa Rica. Cuadernos de investigación UNED, 5(2), 303-306.

Andrés, C. (2013b). Focus Group sobre el desarrollo de productos innovadores a base de Gandul (Cajanus Cajan) en la Cuenca del Río Peñas Blancas de Costa Rica. Cuadernos de Investigación UNED, 5(2), 319-323.

Andrés, C. (2013c). Determinación de los descriptores sensoriales de un dip tipo hummus a base de Gandul (Cajanus cajan) mediante dos mini gropos focales. Cuadernos de investigación UNED, 5(2), 307-318.

Andrés, C.; Amerling, C., \& Saravia, K. (2013). Prueba sensorial de grado de satisfacción para una ensalada y un dip tipohummus elaborados a base de gandul (Cajanus cajan (L.) Millsp.). Repertorio Científico UNED, Handed in to the journal.

Anzaldúa-Morales, A. (1994). La evaluación sensorial de los alimentos en la teoría y la práctica. Zaragoza, España: Acribia.

Gadioli, I.; de Lacerda de Oliviera, L.; Da Silva, J.; Bezerra, A.; Queiroz, I., \& Chiarello, M. (2013). Evaluation of Packing Attributes of Orange Juice on Consumers' Intention to Purchase by Conjoint Analysis and Consumer Attitudes Expectation. Journal of Sensory Studies, 28(1), 57-65. Retrieved from http://onlinelibrary.wiley.com/ doi/10.1111/joss.12023/full

Hartman, H., Wadsworth, D. P., Penny, S., Assema, P. V., \& Page, R. (2013). Psychosocial determinants of fruit and vegetable consumption among students in a New Zealand university: results of focus group interviews. Appetite, 65(1), 35-42. Retrieved from http://www.sciencedirect. com/science/article/pii/S0195666313000585

Ivankovich, C. (2012). Curso Herramientas para el desarrollo de productos innovadores. San José, costa Rica: CITA, UCR.

Katrin, A., \& Ystgaard, K. (2013). Europeans and aquaculture: perceived differences between wild and farmed fish. British Food Journal, 115(2), 209 - 222. Retrieved from http://www.emeraldinsight.com/journals.htm?articleid $=17077383 \&$ show $=$ abstract

Kher, S. V., De Jonge, J., Wentholt, M. T., Deliza, R., de Andrade, J. C., Cnossen, H. J., \& Frewer, L. J. (2013). Consumer perceptions of risks of chemical and microbiological contaminants associated with food chains: a cross-national study. International Journal of Consumer Studies, 37(1),
73-83. Retrieved from http://onlinelibrary.wiley.com/ doi/10.1111/j.1470-6431.2011.01054.x/full

MAG (Ministerio de Agricultura y Ganadería, CR) 1991. Aspectos Técnicos sobre Cuarenta y Cinco Cultivos Agrícolas de Costa Rica. Dirección General de Investigación y Extensión Agrícola. San José, Costa Rica.

McCarthy, M; Cluzel, E; Dressel, K \& Newton, R. (2013). Food and health research in Europe: structures, gaps and futures. Food Policy, 39, 64-71.Retrieved from http://www.sciencedirect.com/science/article/pii/S0306919212001303

Nwosu, J.N.,Ojukwu, M., Ogueke, C.C., Ahaotu, I., \&Owuamanam, C. I. (2013). The Antinutritional Properties and Ease of Dehulling on theProximate Composition of Pigeon pea (Cajanus cajan) as Affected by Malting. Retrieved from http://crdeep.com/wp-content/uploads/2013/05/Vol2-2-1-IJLS.pdf

Pandey, P., Pandey, V., Kumar, R, \& Tiwari, D. (2013). Imperative quality factors which influence nutritional value of pigeonpea [(Cajanus cajan (I.) millsp.)]. Agri-environment: perspectives on sustainable development, 169. Retrieved from http://www.editura.bioflux.com.ro/docs/belgianromanian-book.doc.pdf\#page $=169$

Paul, C., \& Weber, M. (2013). Research Article Intercropping Cedrela odorata with Shrubby Crop Species to Reduce Infestation with Hypsipyla grandella and Improve the Quality of Timber. Retrieved from http://scholar.google. $\mathrm{com} /$ scholar?q=Pigeon+pea\%2C+Panama\&btnG=\&hl= es\&as_sdt $=0 \% 2 C 5 \& a s \_y l o=2013$

Ronner, E., \& Giller, K. E. (2013). Background information on agronomy, farming systems and ongoing projects on grain legumes in Uganda. Characterization Uganda. Retrieved from http://www.n2africa.org/sites/n2africa.org/files/ images/images/N2Africa_Characterizatio\%20Uganda. pdf

Sijtsema, S. J., Zimmermann, K. L., Cvetković, M., Mora, C., \& Zaouche-Laniau, M. (2013). Assessing Fruit Perception Using Focus Groups. In Food Consumer Science (pp. 7387). Netherlands: Springer Netherlands.

Slining, M.; Wen, S., \& Popkin, B. (2013). Food Companies' Calorie-Reduction Pledges to Improve US Diet. American journal of preventive medicine, 44(2), 174-184. Retrieved from http://www.sciencedirect.com/science/article/pii/ S074937971200801X

Stolzenbach, S., Bredie, W. L., \& Byrne, D. V. (2013). Consumer concepts in new product development of local foods: Traditional versus novel honeys. Food Research International, 52(1), 144-152.Retrieved from http:// www.sciencedirect.com/science/article/pii/ S0963996913001245

Veríssimo, M., \& Loureiro, S. M. C. (2013). Experience marketing and the luxury travel industry. Tourism \& Management Studies, 1, 296-302. Retrieved from http://www.tmstudies.net/index.php/ectms/article/view/429 
APPENDIX 1

Flow diagram of the production process of the pigeon pea salad

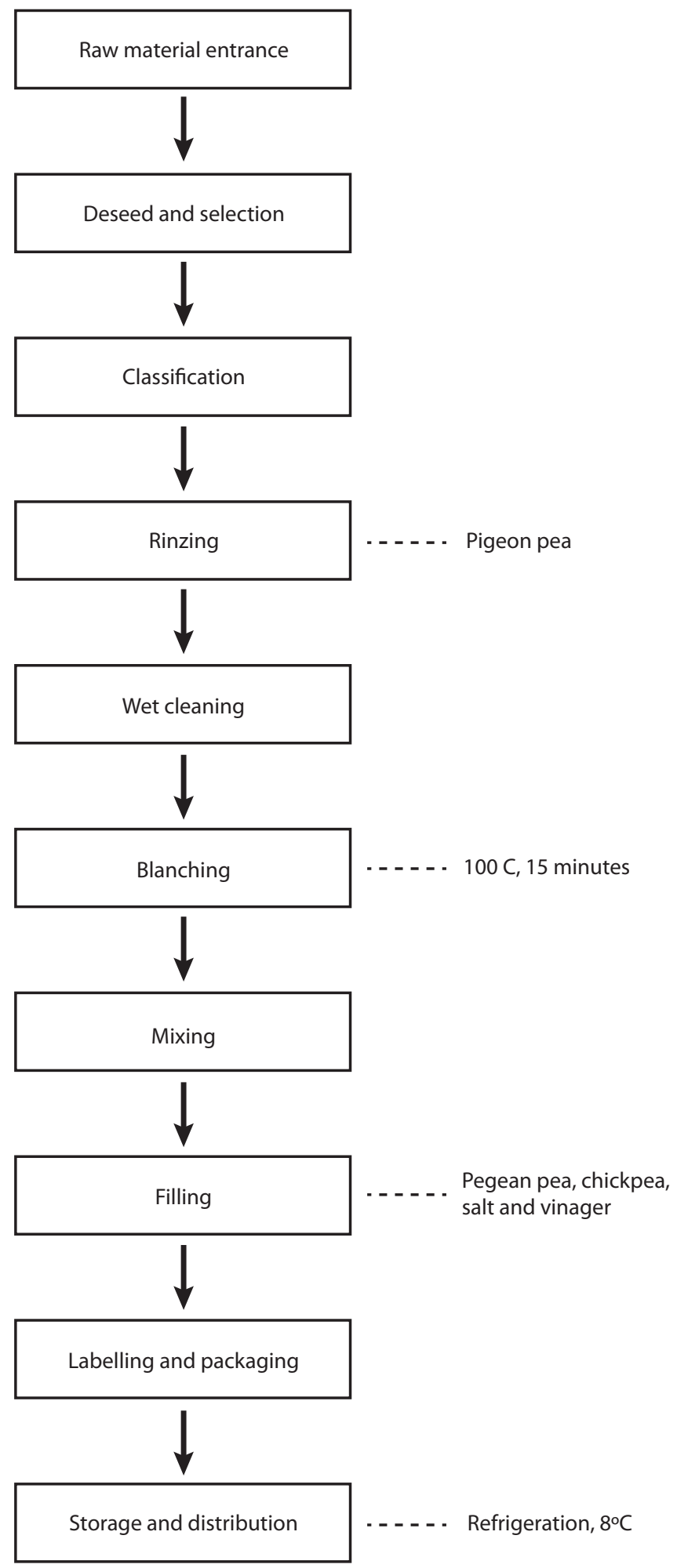


